\title{
Influence of storm surges on intertidal meiofauna of an exposed sandy beach
}

\author{
Luana Dotto Tarragô**, Carla Penna Ozorio
}

\begin{abstract}
Centro de Estudos Costeiros, Limnológicos e Marinhos da Universidade Federal do Rio Grande do Sul (Av. Tramandaí, 976 - Imbé - Rio Grande do Sul - 95625000 - Brazil)

** Correponding author: luanadottot@gmail.com; ozorio@ufrgs.br
\end{abstract}

According to MCLACHLAN; BROWN (2006), sandy beaches are extremely dynamic environments and the interaction of winds, waves, tides and sediments is the main reason for their instability. They are usually more affected by storm surges than by other factors such as pollution and disruption of sediment transport. Storm surges are episodic phenomena caused by a rise in the average expected sea level by an astronomical component associated with weather conditions like cold fronts, hurricanes and cyclones (PUGH, 1987; VIEIRA, RANGEL, 1988). Their impact is higher on exposed beaches with micro-tide regime due to the large amounts of sediment transport and erosion that occur during the phenomenon (MACHADO et al., 2010; MCLACHLAN; BROWN, 2006; VIEIRA; RANGEL, 1988; VILLWOCK; TOMAZELLI, 1995). According to VILLWOCK; TOMAZELLI (1995) and VIEIRA; RANGEL (1988), storm surges are responsible for the most significant sea level oscillations in the sandy beach system of Rio Grande do Sul.

Studies about storm surge effects on sandy beach fauna for the South Atlantic Ocean were carried out by ALVES; PEZZUTO, 2009; COCHÔA et al., 2006; GALLUCI; NETTO, 2004; NEVES; SILVA; BEMVENUTI, 2008 SOLA; PAIVA, 2001. In relation to macrofauna, some patterns begin to appear such as the trapping of organisms in the subaerial zone (NEVES; SILVA; BEMVENUTI, 2008) and alterations in the spacial pattern associated with changes in the position of the swash zone, the moisture gradient and the sea level (ALVES; PEZZUTO, 2009).
For meiofauna, GALUCCI; NETTO (2004) detected the effects of two cold fronts in the shallow sublittoral of a sheltered beach. PALMER; GUST (1985) indicated that variation patterns of this community can be induced by sediment transport and erosion. GIERE (2009) claimed that the massive agitation of sediment caused by storms can destroy some of the less agile meiofaunal components. SILVA; GROHMANN; ESTEVES (1997) argued that the breaking of waves on the beach surface stirs upper layers of sediment and causes suspension of the meiofauna. They also concluded that passive suspension is one of the most important transport mechanisms for the group.

In the last ten years, studies of the influence of storms in meiofauna have been virtually nonexistent. This study provides an approach of how storms can affect meiofauna organisms in the intertidal zone of an exposed subtropical beach whith a micro-tide regime.

The study area is located at Tramandaí beach, coordinates $50^{\circ} 07^{\prime} 50^{\prime \prime} \mathrm{W}$ and $29^{\circ} 56^{\prime} 30^{\prime \prime} \mathrm{S}$ on the northern coast of Rio Grande do Sul, Brazil (Fig. 1). This beach presents a micro-tide regime, morphodynamic states from intermediate to dissipative (TOMAZELLI; VILLWOCK, 2005), average waves of about $1,5 \mathrm{~m}$ (CALLIARI; TOLDO; NICOLODI, 2006) and is in a humid subtropical climate strongly influenced by masses of polar and subtropical air (FERRARO; HASENACK, 2009). According to VILLWOCK; TOMAZELLI (1995) and VIEIRA; RANGEL (1988), the astronomical tide in the region is not very important because it does not cause the largest oscillations of sea level.

Received: November 9, 2015

Approved: August 23, 2016

* Paper presented in the International Sandy Beach Symposium, 7. 2015, Ilhabela, São Paulo, Brazil . 


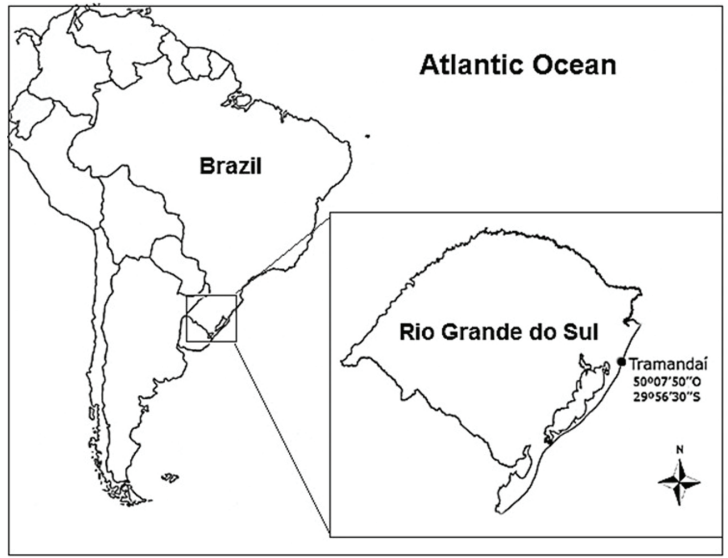

Figure 1. Tramandaí (RS/Brazil) beach localization, where the study site was defined. (Modified from IBGE, 2014).

In the study area, two profiles, A and B, were established, each with six sampling points and separated by a distance of about $450 \mathrm{~m}$. Sampling points were fixed and spaced by $20 \mathrm{~m}$; Point 1 was close to the dunes, while Point 6 was in the swing zone (Fig. 2). At each sampling point, five random samples were taken in $0.25 \mathrm{~m} 2$ using a corer with a diameter of $3 \mathrm{~cm}$ up to $6 \mathrm{~cm}$ deep and fixed with 70\% ethyl alcohol. Organism extraction was accomplished through the addition of saturated $\mathrm{NaCl}$ solution to the sample, which was stirred and poured on a series of sieves with $0.5 \mathrm{~mm}$ and $0.064 \mathrm{~mm}$ mesh. The biological material retained on the $0.064 \mathrm{~mm}$ mesh sieve was analyzed under stereomicroscope for identification and quantification of meiofaunal zoological groups (phylum, class or order).

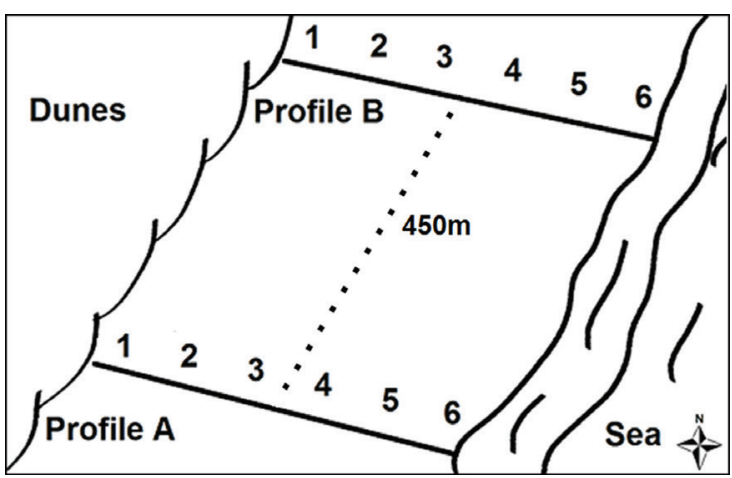

Figure 2. Illustration of profiles (A and B) and points (16) sampling at Tramandaí beach (RS,Brazil) in the meiofauna study from October/2013 to May/2014.

The effects of four storm surges were independently evaluated using Student's t test comparing average meiofaunal group densities before and after the event. As applied by BARLETTA; CALLIARI (2001), PARISE; KRUSCHE; CALLIARI (2009) and MACHADO et al. (2010), sampling days were chosen through daily verification of numerical predictions of the WAVEWATCH III model given by the Weather Forecast and Climatic Studies Center (Centro de Previsão de Tempo e Estudos Climáticos- CPTEC).Sampling occurred 24h before and $24 \mathrm{~h}$ after each event. Wind speed and direction, wave height and wave period data of the events were also obtained on CPTEC.

The first monitored storm surge showed the highest wave height, wind speed and longest duration, with rough sea conditions lasting more than five days. The others were similar in both intensity and duration and lasted approximately five days (Tab. 1).

Table 1. Means and values of wave and wind parameters of four storm surge monitored $24 \mathrm{~h}$ before and $24 \mathrm{~h}$ after from October/2013 to May/2014 at Tramandaí beach (RS/Brazil).

\begin{tabular}{|c|c|c|c|c|c|c|}
\hline Event & Condition & Date & Waves height & Waves period & Wind direction & Wind speed \\
\hline \multirow{3}{*}{ I } & Before & $10 / 09 / 2013$ & $1.0 \mathrm{~m}$ & $5 \mathrm{~s}$ & $\mathrm{NE}$ & $10 \mathrm{~m} / \mathrm{s}$ \\
\hline & After & $11 / 07 / 2013$ & $2.0 \mathrm{~m}$ & $6,3 \mathrm{~s}$ & SE & $12 \mathrm{~m} / \mathrm{s}$ \\
\hline & Average & & $3.0 \mathrm{~m}$ & $6.8 \mathrm{~s}$ & SE & $16 \mathrm{~m} / \mathrm{s}$ \\
\hline \multirow{3}{*}{ II } & Before & $01 / 24 / 2014$ & $0.8 \mathrm{~m}$ & $5,8 \mathrm{~s}$ & $\mathrm{NE}$ & $5,4 \mathrm{~m} / \mathrm{s}$ \\
\hline & After & $01 / 29 / 2014$ & $0.7 \mathrm{~m}$ & $6.2 \mathrm{~s}$ & $\mathrm{NE}$ & $2,2 \mathrm{~m} / \mathrm{s}$ \\
\hline & Average & & $2.0 \mathrm{~m}$ & $8.0 \mathrm{~s}$ & S & $11 \mathrm{~m} / \mathrm{s}$ \\
\hline \multirow{4}{*}{ III } & Before & $03 / 26 / 2014$ & $1.2 \mathrm{~m}$ & $9.8 \mathrm{~s}$ & SE & $5,0 \mathrm{~m} / \mathrm{s}$ \\
\hline & After & $04 / 03 / 2014$ & $2.0 \mathrm{~m}$ & $6.2 \mathrm{~s}$ & SE & $8,0 \mathrm{~m} / \mathrm{s}$ \\
\hline & Average & & $2.0 \mathrm{~m}$ & $6.4 \mathrm{~s}$ & $\mathrm{~S} / \mathrm{SE}$ & $12 \mathrm{~m} / \mathrm{s}$ \\
\hline & Before & $05 / 22 / 2014$ & $1.2 \mathrm{~m}$ & $7.4 \mathrm{~s}$ & $\mathrm{NE}$ & $4,8 \mathrm{~m} / \mathrm{s}$ \\
\hline \multirow[t]{2}{*}{ IV } & After & $05 / 28 / 2014$ & $1.4 \mathrm{~m}$ & $10.7 \mathrm{~s}$ & $\mathrm{NE}$ & $5,3 \mathrm{~m} / \mathrm{s}$ \\
\hline & Average & & $2.0 \mathrm{~m}$ & $8.0 \mathrm{~s}$ & $\mathrm{~S} / \mathrm{SE}$ & $9 \mathrm{~m} / \mathrm{s}$ \\
\hline
\end{tabular}


Meiofauna was comprised of eight taxonomic groups: Nematoda (65\%), Turbellaria (20\%), Copepoda Harpacticoida (12\%), Oligochaeta (3\%), Acari $(<1 \%)$, Polychaeta $(<1 \%)$, Gastropoda $(<1 \%)$ and Insecta $(<1 \%)$, the last three of which are members of temporary meiofauna.

Student's t-test results for the four most abundant groups and total meiofauna are found in Table 2. The October storm surge was the most influent event as its effect was statistically identified in $60 \%$ of comparisons, followed by the events of January (33.3\%), May (30\%) and March $(20 \%)$. In the October and January storms, a meiofauna density increase after $24 \mathrm{~h}$ was observed in $88.8 \%$ and $80 \%$ (respectively) of the significant t-test results. In the March and May storms, the meiofauna density increase after $24 \mathrm{~h}$ occurred in just $33 \%$ and $22 \%$ (respectively) of the significant t-test results.

Table 2. Results of Student's t-Test (a: 0,05) for meiofauna organisms. Painted cells denote significant differences between averages before and after; $(>)$ average before storm is higher than after and $(<)$ average after storm is higher than before.

\begin{tabular}{|c|c|c|c|c|c|c|c|c|c|c|c|c|}
\hline October storm & 1 & $\mathbf{p}$ & 2 & $\mathbf{p}$ & 3 & $\mathbf{p}$ & 4 & $\mathbf{p}$ & 5 & $\mathbf{p}$ & 6 & $\mathbf{p}$ \\
\hline Nematoda & & 0,41 & $<$ & 0.00 & $<$ & 0.00 & & 0.5 & & 0.22 & $<$ & 0.01 \\
\hline Turbellaria & $>$ & 0.00 & $<$ & 0.00 & $<$ & 0.04 & $>$ & 0.01 & & 066 & $<$ & 0.00 \\
\hline Harpacticoida & & - & & - & & - & $<$ & 0.04 & & 0.07 & $<$ & 0.00 \\
\hline Oligochaeta & $<$ & 0.00 & $<$ & 0.00 & $<$ & 0.04 & $<$ & 0.01 & & 0.88 & $<$ & 0.02 \\
\hline Total Meiofauna & & 0.15 & $<$ & 0.00 & $<$ & 0,00 & & 0.16 & & 0.75 & $<$ & 0.00 \\
\hline January storm & 1 & $\mathbf{p}$ & 2 & $\mathbf{p}$ & 3 & $\mathbf{p}$ & 4 & p & 5 & $\mathbf{p}$ & 6 & $\mathbf{p}$ \\
\hline Nematoda & $<$ & 0.04 & & 0.25 & & 0.44 & $<$ & 0.02 & & 0.26 & & 0.39 \\
\hline Turbellaria & & 0.97 & & 0.87 & & 0.62 & $>$ & 0.02 & $<$ & 0.00 & & 0.22 \\
\hline Harpacticoida & & - & & - & & - & $>$ & 0.00 & & 0.60 & $<$ & 0.01 \\
\hline Oligochaeta & $<$ & 0.00 & $<$ & 0.04 & & 0.80 & & - & & 0.33 & & - \\
\hline Total Meiofauna & $<$ & 0.02 & & 0.58 & & 0.43 & & 0.52 & & 0.29 & $<$ & 0.02 \\
\hline March stom & 1 & $\mathbf{p}$ & 2 & $\mathbf{p}$ & 3 & $\mathbf{p}$ & 4 & $\mathbf{p}$ & 5 & $\mathbf{p}$ & 6 & $\mathbf{p}$ \\
\hline Nematoda & & 0.33 & & 0.68 & $>$ & 0.00 & $<$ & 0.00 & $>$ & 0.03 & & 0.07 \\
\hline Turbellaria & & 0.91 & & 0.333 & & 0.23 & & 0.10 & & 0.07 & & 0.50 \\
\hline Harpacticoida & & - & & - & & - & $>$ & 0.01 & & 0.40 & & 0.08 \\
\hline Oligochaeta & & 0.86 & & 0.89 & & 0.95 & & 0.21 & & 0.18 & & - \\
\hline Total Meiofauna & & 0.36 & & 0.61 & $>$ & 0.00 & $<$ & 0.00 & & 0.12 & & 0.18 \\
\hline May storm & 1 & $\mathbf{p}$ & 2 & p & 3 & $\mathbf{p}$ & 4 & $\mathbf{p}$ & 5 & $\mathbf{p}$ & 6 & $\mathbf{p}$ \\
\hline Nematoda & & 0.80 & $>$ & 0.03 & & 0.08 & & 0.90 & $>$ & 0.00 & & 0.30 \\
\hline Turbellaria & $<$ & 0.04 & $>$ & 0.02 & & 0.33 & & 0.78 & & 0.34 & & 0.69 \\
\hline Harpacticoida & & - & & - & & - & & 0.44 & & 0.07 & $<$ & 0.05 \\
\hline Oligochaeta & $>$ & 0.03 & $>$ & 0.01 & & 0.33 & & 0.33 & & - & & - \\
\hline Total Meiofauna & & 0.43 & $>$ & 0.00 & & 0.24 & & 0.31 & $>$ & 0.03 & & 0.07 \\
\hline
\end{tabular}

Points 2, 4 and 6 were more affected than the others because significant differences were observed in $45 \%$ and $40 \%$ of comparisons (Tab. 2). In Point 2, after the October storm, the majority of organisms was increased, while after the May storm, they decreased. In Point 4, significant changes in the average densities were not observed; only in the May storm, although the variation pattern was not regular. In relation to Point 6 , the average densities were always higher after the four events.

Similarly, Copepoda Harpacticoida was the most vulnerable group; its average densities were statistically different in $50 \%$ of comparisons. Generally, after the storm, this group showed a reduction in Point 4 and a raise in Point 6.

In figures 3,4 and 5, the variation patterns above mentioned can be better analyzed. 

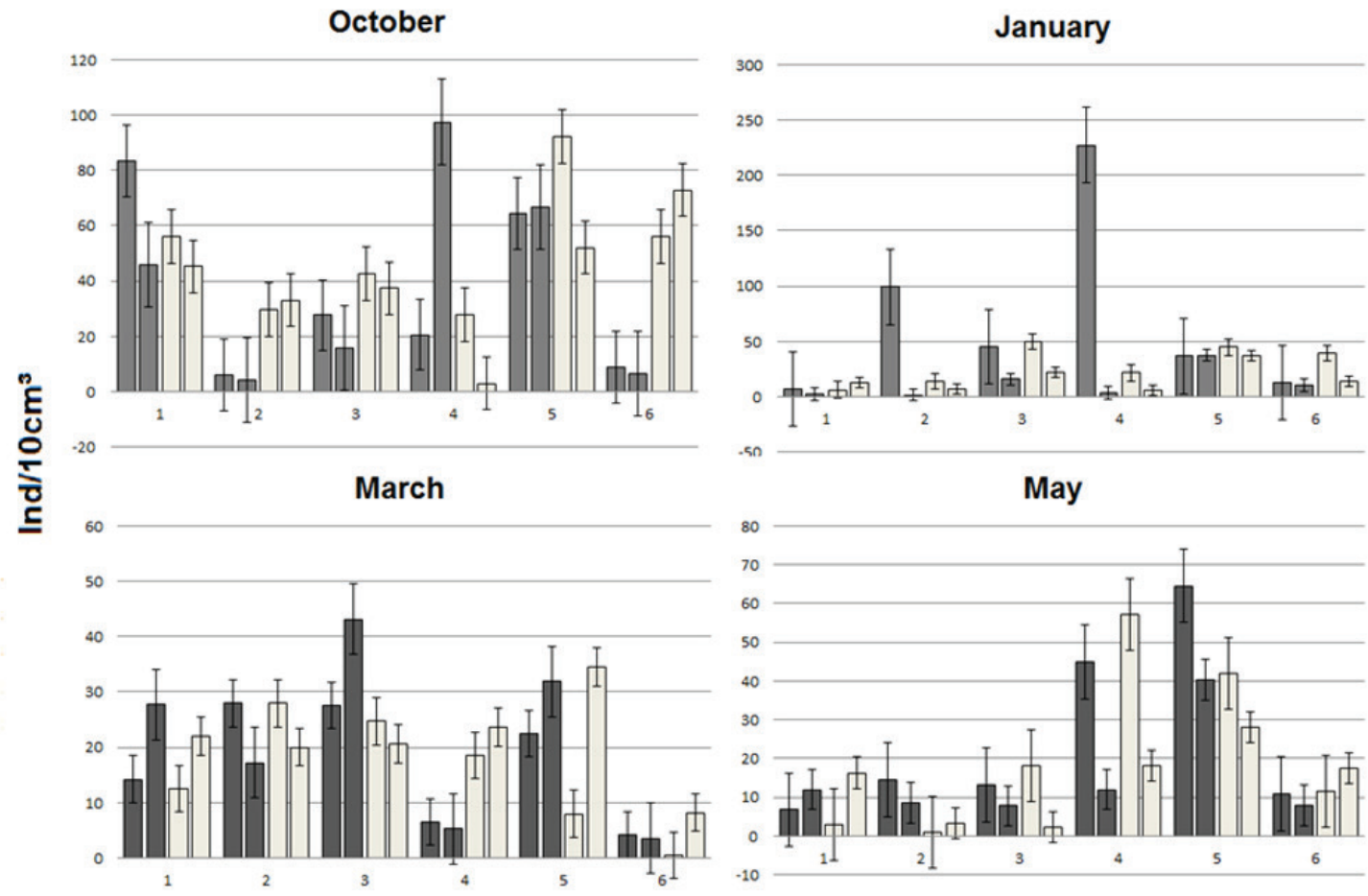

Figure 3. Average Densities for total meiofauna in four storm surges from October/2013 to May/2014 at Tramandaí beach (RS/Brazil). Dark bars: profiles A and B 24h before the event; white bars: profiles A and B 24h after event; 1: sampling point nearest the dunes; 6 : sampling point nearest the sea.
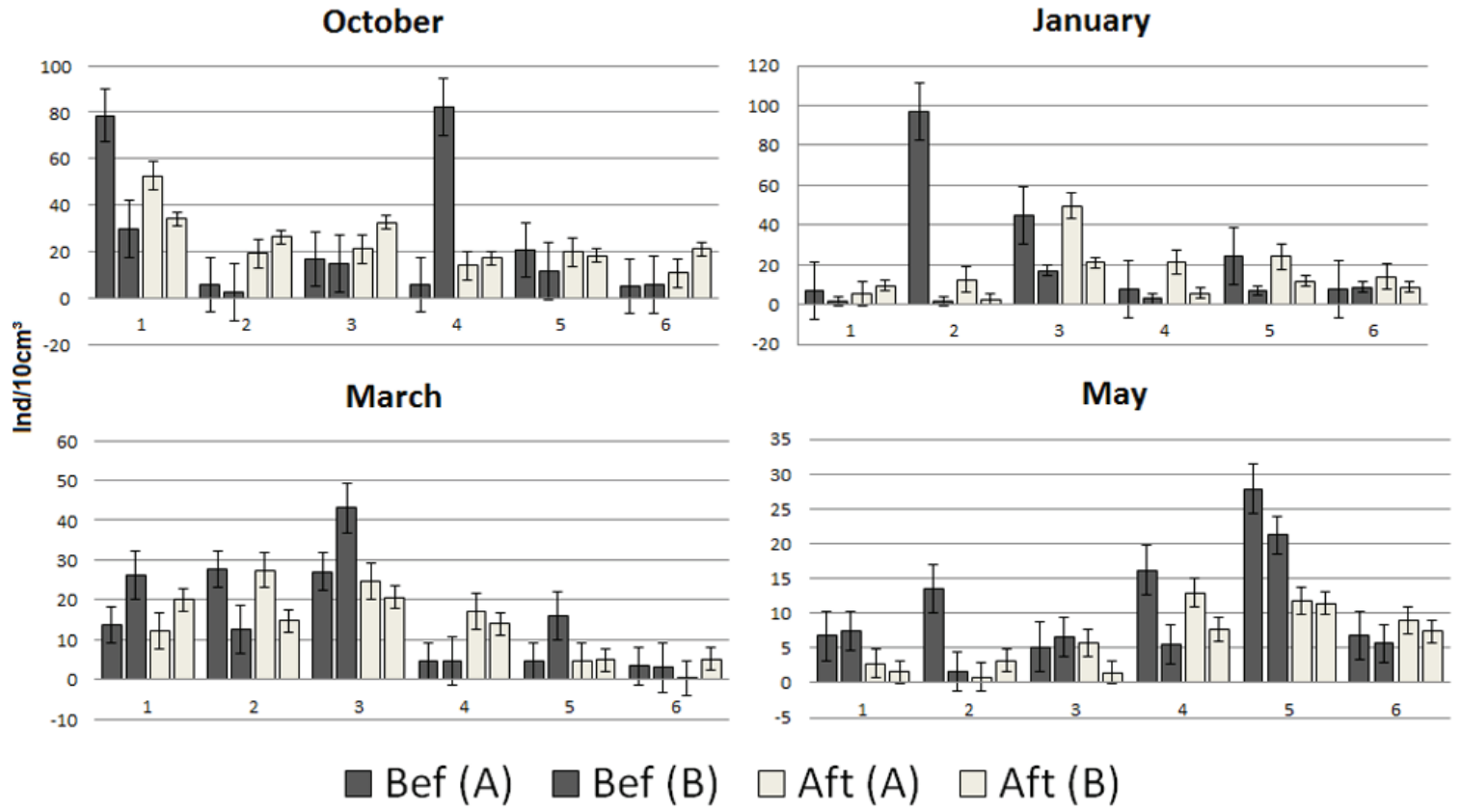

Figure 4. Average Densities for Nematoda 24h before and 24h after four storm surges from October/2013 to May/2014 at Tramandaí beach (RS/Brazil). 


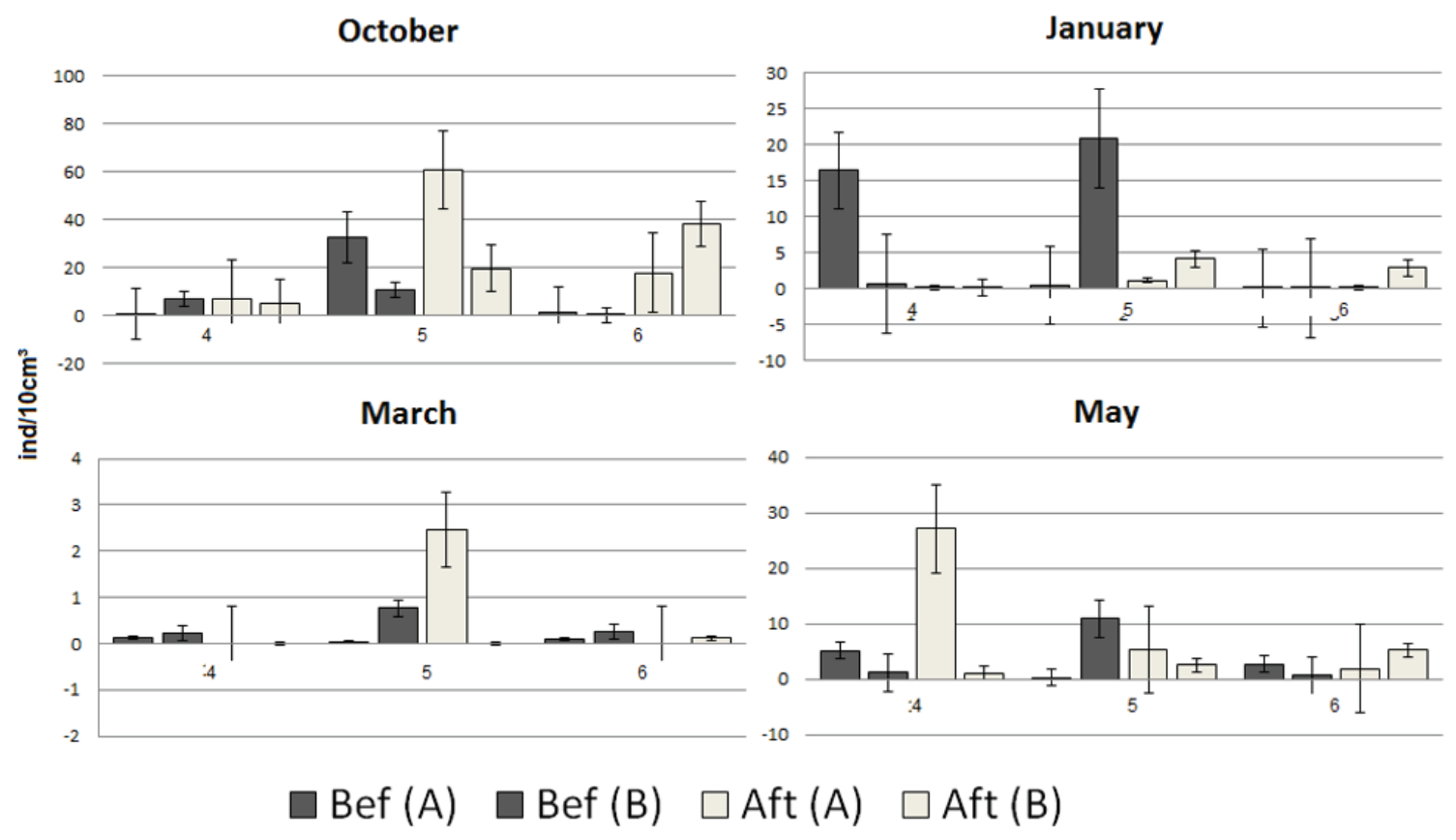

Figure 5. Average Densities for Copepoda Harpacticoida 24h before and 24h after four storm surges from October/2013 to May/2014 at Tramandaí beach (RS/Brazil).

The meiofaunal composition, in terms of higher taxa levels, was similar to previous studies around the world done on sandy beaches, showing Nematoda, Turbellaria and Harpacticoida as the most abundant groups with densities similar to those already recorded (GIERE, 2009). The spatial distribution of meiofauna along the intertidal zone follows patterns related with ecological needs, mainly of interstitial water. As an example, Turbellaria occurrence is mostly determined by sedimentary water content among all the other abiotic factors (GIERE, 2009).

Water saturations in the intertidal zone are greatly defined by sea level elevations and precipitation, phenomena especially associated with storm surge in the study area since it does not have a significant astronomic tide (TOMAZELLI; VILLWOCK, 2005). On the other hand, rarely, meiofauna movement perpendicular to the waterline occurs dissociated of local hydrodynamics, in this case, mainly determined by storm surges. SILVA; GROHMANN; ESTEVES (1997) mention that a common transport for meiofaunal groups is precisely through wave hydrodynamics. When the waves break, they stir up the sediment and suspend the organisms, carrying them away.

Despite large variation on t-test results for the four events, they indicated that some effect takes place on group densities along the profiles. The storm effect can be positive, increasing the organism number or negative, reducing it at the sampling points. This variability is likely due to the material transport that occurs during the drastic change of sea level. For example, the Harpacticoida increase at point 6 , closest to the sea, after the storm is probably due to the organisms brought from superior strata to this place by the sea water. According to several authors (BARLETTA; CALLIARI, 2001; MCLACHLAN; BROWN, 2006; VIEIRA; RANGEL, 1988; WESCHENFELDER; ZOUAIN, 2002), beach sediments are carried to marine systems through erosive processes during storm surge and, consequently, the meiofauna associated with them must be disturbed in the same way. PALMER; GUST'S (1985) affirm that small benthic individuals undergo erosive impacts just like sediments.

The storm surge influence on the meiofauna distribution along the beach profile was different from that reported for macrofauna. While the macrofauna moves towards the superior strata, where it occsionally remains stranded after storm surges (ALVES; PEZZUTO, 2009; NEVES; SILVA; BEMVENUTI, 2008), the meiofauna seems to increase its density in lower strata, which receive sediments and organisms carried by waves.

Remobilization occurs more easily with organisms that live near the substrate surface and that do not have 
reasonable digging skills to move toward deeper layers during the disturbance (such as Harpacticoida copepods). Thus, it seems quite possible that the variation found in Harpacticoida densities between before and after the storm is due to wave transport during the events. Although nematodes have greater digging skills than Harpacticoida copepods, they can also be inevitably affected by the storm surges. GIERE (2009) claims that some Nematoda species are epibenthic, and as such are also greatly vulnerable to wave transport.

Certainly, the meiofauna response to the storms varied very much among the sampling points because of the great heterogeneity of the beach system and of the analyzed events. Profiles A and B did not have exactly the same conditions; for example, small variations of relief could determine differences in meiofauna distribution along them before the storm and independent of wave action. Additionally, the morphology of off shore sandbars influences the hydrodynamics of waves and currents that act upon the beach face (WESCHENFELDER; ZOUAIN, 2002). In relation to the storm surges, they all had distinct intensities and durations, and consequently their impacts were felt more by the meiofauna on certain occasions than on others.

From this study it was possible to verify that storm surges act upon the structure of intertidal meiofauna, especially changing organism distribution along the beach profile. This response may be large or small, and positive or negative depending on event intensity, beach morphology and ecological features of the zoological groups, especially mobility. The lack of a standardized variation of organism densities along the sampling points and in the analyzed events demonstrated how meiofauna interactions with storms can be complex, making it difficult to predict and generalize the actual effects. Definitely, long term studies, vertical variation studies and simulation experiments will help to measure and to better assess the impact caused by these phenomena on meiofauna in sandy beach communities.

\section{REFERENCES}

ALVES, E.S.; PEZZUTO, P.R. Effect of cold fronts on the benthic macrofauna of exposed sandy beaches with contrasting morphodynamics. Braz. J. Oceanogr., São Paulo, v. 57, n. 2, p. 73-96, 2009.

BARLETTA R.C.; CALLIARI L. J. Determinação da intensidade das tempestades que atuam no litoral do Rio Grande do Sul, Brasil. PSQ., Porto Alegre, v. 28, p. 117-124. 2001

CALLIARI, L. J.; TOLDO JR, E. E.; NICOLODI, J. L. Rio Grande do Sul: classificação geomorfológica. In: MUEHE, D. (Org.) Erosão e progradação no litoral brasileiro. Brasília: MMA, 2006. Available from: Acessed in: 13 Aug. 2013.
COCHÔA, A. R.; LORENZI, L.; BORZONE, C. A. A influência da passagem de uma frente meteorológica na distribuição da macrofauna bentônica mesolitoral de uma praia arenosa exposta. Trop. Oceanogr., Recife, v. 34, n. 2, p. 59-71, 2006

FERRARO, L. W.; HASENACK, H. Clima. In: Würdig, N. L. \& Freitas, S. M. F. de (Org.). Ecossistemas e biodiversidade do Litoral Norte do RS. Nova Prova: Porto Alegre, p. 26-31. 2009.

GALLUCCI, F.; NETTO, S. A. Effects of the passage of cold fronts over a coastal site: an ecosystem approach. Mar. Ecol. Prog. Ser, Amelinghausen, v. 281, p. 79-92. 2004. Available from: Accesed in: 11 Mar. 2014.

GIERE, O. Meiobenthology: the microscopic motile fauna of aquatic sediments. 2nd ed. Berlin: Springer, 2009. 538p

MACHADO, A.A.; CALLIARI, L.J.; MELO, E.; KLEIN, A.H.F. Historical assessment of extreme coastal sea state conditions in southern Brazil and their relation to erosion episodes. PanAm. J. Aquat. Sci., v.5, n. 2, p. 277-286, 2010.

MCLACHLAN, A.; BROWN, A. The ecology of sandy shores. 2nd ed. Amsterdam: Academic Press, 2006. 392 p.

NEVES, L. P. das; SILVA, P. de S. R. da; BEMVENUTI, C. E. Temporal variability of benthic macrofauna on Cassino beach, southernmost Brazil. Iheringia, Sér. Zool., Porto Alegre, v. 98, n. 1, p. 36-44, 2008. Available from . Accesed in: 27 Sept. 2015

PALMER, M. A.; GUST, G. Dispersal of meiofauna in a turbulent tidal creek. J. Mar. Res., New Haven, USA, v. 43, p. 179-210. 1985. Available from < http://dx.doi. org/10.1357/002224085788437280> Accessed in: 27 Oct. 2015

PARISE, C. K.; CALLIARI, L. J.; KRUSCHE, N. Extreme storm surges in the south of brazil: atmospheric conditions and shore erosion. Braz. J. Oceanogr., São Paulo, v. 57, n.3, p. 175-188, 2009.

PUGH, D. T. Tides, surges and mean sea level. Chichester, U.K.: Jonh Wiley, 1987. 472 p.

SILVA, V. M. A. P.; GROHMANN, P. A.; ESTEVES, A. M. Aspectos gerais do estudo da meiofauna de praias arenosas. Oecol. Bras., Rio de Janeiro, v. 3, n.1, p. 67-92. 1997

SOLA, M. C. R.; PAIVA, P. C. Variação da macrofauna bentônica sublitoral da praia da Urca (RJ) após a ocorrência de ressacas. Braz. J. of Oceanogr., São Paulo, v. 49, n. 1-2, p. 137-142, 2001. Available from: < http://www.scielo.br/pdf/bjoce/ v49n1-2/12.pdf $>$ Acessed in: 28 Oct. 2015

TOMAZELLI, L. J.; VILLWOCK, J. A. Mapeamento geológico de planícies costeiras: o exemplo da costa do Rio Grande do Sul. GRAVEL, Porto Alegre, n. 3, p. 109-115. 2005. Available from Acessed in: 16 May 2013

VIEIRA, E. F.; RANGEL, S. R. S. Planicie Costeira do Rio Grande do Sul: geografia física, vegetação e dinâmica sóciodemográfica. 1 ed. Sagra: Porto Alegre, 256 p. 1988.

VILLVOCK, J. A.; TOMAZELLI, L. J. Geologia Costeira do Rio Grande do Sul. Notas Técnicas (CECO/IG/UFRGS), Porto Alegre, n. 8, p. 1-45. 1995

WESCHENFELDER, J.; ZOUAIN, R. N. A. Variabilidade morfodinâmica das praias oceânicas entre Imbé e Arroio do Sal, RS, Brasil. PSQ., Porto Alegre, v. 29, n. 1, p. 3-13. 2002. Available from: < http://www.ufrgs.br/igeo/pesquisas/2901/01-2901.pdf $>$ Accesed in: 10 Aug. 2013 